Arabic sciences and philosophy, 31 (2021): 225-256

doi:10.1017/S0957423921000072

(C) The Author(s), 2021. Published by Cambridge University Press. This is an Open Access article, distributed under the terms of the Creative Commons Attribution licence (http://creativecommons.org/licenses/by/4.0/), which permits unrestricted re-use, distribution, and reproduction in any medium, provided the original work is properly cited.

\title{
PAUL KRAUS, RICHARD WALZER, AND GALEN'S COM. TIM.
}

\author{
AILEEN R. DAS \\ University of Michigan \\ Email:ardas@umich.edu
}

\begin{abstract}
A key work for the study of pre-modern Platonism, Galen's (d. ca. 217 CE) "Synopsis of Plato's Timaeus" (Com. Tim.) is served solely by an "imperfect" 1951 edition that presents for the first time the surviving Arabic text and translates it into Latin. The editors of the "Plato Arabus" series of the Corpus Platonicum, to which the edition belongs, blamed its flaws on the untimely death of Paul Kraus (1904-1944), who prepared the edition with another Jewish refugee Richard Walzer (1900-1975) around WWII. My analysis of archival sources will demonstrate that the labor on the volume was disproportionately Kraus', whom Walzer and the Corpus Platonicum editor Raymond Klibansky (1905-2005) marginalized from the project in their attempts to secure employment in British academia as displaced Jews. I will also consider how Walzer and Klibansky re-envisioned Kraus' plans for a Semitic corpus of Platonism to a narrower "Plato Arabus" that would align with a study of Latin Platonism ("Plato Latinus") in which they presumed their British patrons would be more interested.
\end{abstract}

Résumé. Le "Synopsis du Timée de Platon » de Galien (217 apr. J.-C.), ouvrage clé pour l'étude du platonisme prémoderne, survit uniquement dans une édition dite " imparfaite " de 1951 qui présente pour la première fois le texte arabe survivant accompagné de sa traduction en latin. Les rédacteurs de la série "Plato Arabus » du Corpus Platonicum, à laquelle l'édition appartient, ont attribué les défauts de cette édition à la mort inopportune de Paul Kraus (1904-1944), qui l'a préparée, aidé par un autre réfugié juif, Richard Walzer (1900-1975), pendant la période de la seconde guerre mondiale. Notre analyse de sources tirées d'archives démontrera que le travail sur ce volume était majoritairement celui de Kraus. Qui plus est, nous démontrons que Walzer et le rédacteur du Corpus Platonicum Raymond Klibansky (1905-2005) ont marginalisé le travail de Kraus sur le projet dans l'optique d'avancer leurs propres carrières universitaires en tant que Juifs réfugiés en Grande-Bretagne. Nous allons également examiner la manière dont Walzer et Klibansky ont remanié le projet initial de Kraus - celui d'un corpus sémitique du platonisme - en un "Plato Arabus " plus étroit qui s'alignerait sur une étude du platonisme latin ( Plato Latinus»), projet qu'ils présumaient plus susceptible d'intéresser leurs mécènes britanniques.

Galen of Pergamum's (d. ca. $217 \mathrm{CE}$ ) "Synopsis of Plato's Timaeus" (hereafter Com. Tim.) seems to have offered pre-modern readers of Arabic a more comprehensive overview of the Timaeus than other available 
sources in Arabic. Accordingly, it had not only a substantial role in the reception of the dialogue but also a pervasive presence in early medieval thought in the Islamicate world. ${ }^{1}$ Extant for the most part only in Arabic, Galen's abridgement is at the present served solely by the 1951 editio princeps, prepared by two Jewish refugee scholars Paul Kraus (1904-1944) and Richard Walzer (1900-1975), whose text and modern Latin translation show, in the words of the editorial preface, "many imperfections." 2 The edition was supposed to be the inaugural volume although it was actually published second - of the Plato Arabus series of the Corpus Platonicum, which the historian of philosophy Raymond Klibansky (another Jewish émigré) directed with the support of the British Academy and Warburg Institute. ${ }^{3}$ The editorial preface reports that, in addition to the untimely death of Paul Kraus, WWII's ex-

${ }^{1}$ On the contribution of Com. Tim. to Arabic thinkers' knowledge of Plato's Timaeus, see Rüdiger Arnzen, "Plato's Timaeus in the Arabic tradition. Legends-testimoniesfragments," in Francesco Celia and Angela Ulacco (ed.), Il Timeo. Esegesi greche, latine, arabe (Pisa, 2012), 181-276, and Aileen Renée Das, Galen and the Arabic reception of Plato's Timaeus (Cambridge, 2020). For the abridgement's impact on early medieval Islamicate philosophy, see Peter Adamson, "Platonic pleasures in Epicurus and al-Râzî," in Peter Adamson (ed.), In the age of al-Fārābī: Arabic philosophy in the fourth / tenth century (London, 2008), 71-94, and Pauline Koetschet, Abū Bakr al-Rāzī, Doutes sur Galien: Introduction, edition et traduction (Berlin and Boston, 2019), xi-cxxxi (passim); on mathematics, see Nicolas Rescher, "Al-Kindī's Treatise on the Platonic solids," in Studies in Arabic philosophy (Pittsburgh 1968), 15-37, and Marwan Rashed, "Thābit ibn Qurra, la Physique d'Aristote et le meilleur des mondes," in Roshdi Rashed (ed.), Thābit ibn Qurra. Science and philosophy in ninthcentury Baghdad (Berlin, 2009), 675-714; on medicine, see Peter Pormann, "AlKaskarī (10th cent.) and the quotations of classical authors: A philological study," in Iwan Garofalo, Alessandro Lami, and Amneris Roselli (ed.), Sulla tradizione indiretta dei testi medici greci: Atti del II Seminario Internazionale di Siena Certosa di Pontignano, 19-20 settembre 2008 (Rome, 2009), 107-39; and kalām theology, see Gregor Schwarb, "Early kalām and the medical tradition," in Peter Adamson and Peter Pormann (ed.), Philosophy and medicine in the Islamicate world (London, 2017), 104-169.

${ }^{2}$ Galen, Compendium Timaei Platonis aliorumque dialogorum synopsis quae extant fragmenta, ed. Paul Kraus and Richard Walzer (London, 1951), vi. See also the "corrigenda et addenda" at ibid., vii-xii. See Marwan Rashed, "Le prologue perdu de l'abrégé du Timée," Antiquorum philosophia, 3 (2009), 89-100, who argues that the preface of Com. Tim. survives in embedded form in the Arabo-Latin magical treatise "Book of laws" (Liber aneguemis $=$ Kitāb al-nawāmīs). Aileen Das and Pauline Koetschet are currently preparing an English translation of Com. Tim., with notes and an introduction, for Cambridge University Press' "Galen into English" project.

${ }^{3}$ It was published after Franz Rosenthal and Richard Walzer's edition of al-Fārābì's "Philosophy of Plato" (Falsafat Aflātūn) - Alfarabius de Platonis philosophia (London, 1943). 
acerbation of long-standing communication issues with the press, Imprimerie catholique de Beyrouth, which had received the manuscript in 1939 , delayed the production of the volume. ${ }^{4}$

This apologetic notice gives the impression that the edition of Com. Tim. was near completion about five years before Kraus' death; it leaves unclear what work remained for him to fulfill. The volume never addresses the division of labor between the two editors, a lack of clarity for which subsequent co-authored publications in the Corpus Platonicum would be criticized, nor does Walzer elucidate the matter when reminiscing about his collaboration with Kraus in his biographical address to the Oxford Near East History Group in $1967 . .^{5}$ In their applications to the Academic Assistance Council for Displaced Scholars (later the Society for the Protection of Science and Learning), a British organization founded in 1933 to provide short-term grants to refugee academics with the goal of finding them more permanent employment, Kraus and Walzer self-identify as experts respectively in "Semitic Philology and Islamic Culture" and "Classical Philology and Oriental Studies" (klassische Philologie und Orientalistik). ${ }^{6}$ The popular presumption has been that their workload fell along these disciplinary lines, with Kraus the

${ }^{4}$ Kraus committed suicide on 12 October 1944 - two months shy of his fortieth birthday - in his apartment in Zamalek, Cairo. On the circumstances surrounding his death, see Joel L. Kraemer, "The death of an orientalist: Paul Kraus from Prague to Cairo," in Martin S. Kramer (ed.), The Jewish discovery of Islam: Studies in honor of Bernard Lewis (Tel Aviv, 1999), 181-223.

${ }^{5}$ In his review of Raymond Klibansky and Carlotta Labowsky's edition of William of Moerbeke's Latin translation of Proclus' commentary on the Parmenides (the third volume of the Plato Latinus sub-series of the Corpus Platonicum), Paul O. Kristeller ("Plato Latinus by Corpus Platonicum Medii Aevi, Raymundus Klibansky; Volumen II: Phaedo by Henrico Aristippo, Laurentius Minio-Paluello, H. J. Drossaart-Lulofs; Volumen III: Parmenides usque ad finem Primae Hypothesis nec non Procli Commentarium in Parmenidem by Guillelmo de Moerbeka, Raymundus Klibansky, Carlotta Labowsky," Journal of philosophy, vol. 53 no. 5 [1956], 196-201, at p. 199) criticizes its failure to define the authors' respective contributions. See Richard Walzer, "Formation of a scholar: The stages on my way," British journal of Middle East studies, vol. 18 no. 2 (1991), 159-68, at 165.

6 Their applications are collected in the Archive of the Society for the Protection of Science and Learning (hereafter SPSL) at the Bodleian Library, Oxford. The holograph version of Kraus' application (MS SPSL 513/1-4, fol. 43), which is written in English on an index card, records that his subject is "oriental," encompassing "Islam, assyriology, semitics, history of science, religion and philosophy in Islam, hellenism in Orient." Walzer's application (MS SPSL 297/1-3, fol. 33), which is in German, is filed with documents pertaining to refugee "classical philologists;" it enters as his special fields "greek philosophy, historiography, and medicine" (griechische Philosophie, Geschichtsschreibung, Medizin). 
"orientalist" being in charge of the Arabic and Walzer the "classicist" the Latin in the volume. Based on my study of letters and holograph, ribbon, and typescript drafts of the edition of Com. Tim. constituting the Paul Kraus Papers at the University of Chicago, the Richard Walzer Archive at the National Library of Israel, and the Archive of the SPSL at the Bodleian Library, this article aims to delineate Kraus and Walzer's responsibilities for the making of the "first" volume of Plato Arabus and to illuminate how historical factors - their forced emigration and the precariousness of their academic posts in diaspora - shaped this making. 7

Tracing the development of the editio princeps of Com. Tim. and the Plato Arabus program, the vertical textual history that follows has four objectives. $^{8}$ (1) I will reveal that the published text of Com. Tim. does not represent the authorized final version of the edition, for it was produced from proofs that were superseded by a revised copy containing readings from a more recently discovered Istanbul manuscript. ${ }^{9}$ (2) The distribution of labor on the volume does not neatly coincide with Kraus and Walzer's self-proclaimed fields of study: while Kraus dealt with the Arabic text, his (now lost) French and German translations of the synopsis appear to have served as the foundation for Walzer's Latin version, which he also reworked to be less "slavish" (sklavisch) to the Arabic. (3) My analysis of the correspondence in the archives will show that these scholars' edition was promised to another publication when Klibansky became aware of their output. As I will propose, the advanced

${ }^{7}$ See Paul Kraus, Papers [Box 2, Folder 4; Box 22, Folder 15; Box 22, Folder 18; Box 26, Folders 17-20], Special Collections Research Center, University of Chicago Library. On the collection and transfer of the papers after Kraus' death to the University of Chicago, see Kraemer, “The death of an orientalist," p. 208-10. See ARC. 4* 1656, Richard Walzer Archive, Archives department, National Library of Israel. My transcriptions of the German documents from the Walzer Archive preserve the original spelling, including the inconsistency in denoting umlaut with diacritical dots and the addition of "e" to the affected vowel.

${ }^{8}$ It is worth reiterating the observation of theorists of the archive that collections are always selective, so archival sources can only provide a partial history of a work's genesis. For a cross-disciplinary look at the challenges confronting archival researchers, see Marlene Manoff, "Theories of the archive from across the disciplines," Portal: Libraries and the academy, vol. 4, no. 1 (2004), 9-25, and Francis Blouin and William G. Rosenberg, Processing the past: Contesting authority in history and the archives (Oxford, 2011).

${ }^{9}$ It is imperative that future work on Galen's summary consult these readings and other changes, which feature in the list of "corrigenda et addenda" at the front of the published edition (see Kraus and Walzer, Compendium Timaei, vii-xii), before reproducing Kraus and Walzer's Arabic text. 
state of the edition appears to have attracted Klibansky's attention because he could leverage its impending completion to demonstrate to potential funding sources the feasibility of his own larger Corpus Platonicum project. (4) The exchanges between Walzer and Klibansky expose tensions between themselves and Kraus that stem from their vulnerability as refugees. All three had lost their university positions in Germany owing to anti-Jewish legislation and were in contingent employment during the composition of Com. Tim. Walzer and Klibansky's letters suggest that economic motives may underlie their editorial sidelining of Kraus, whose research on the writings attributed to the alchemist Ğābir ibn Hayyān (first half of the 2nd / 9th c.) appears to have stimulated his interest in Com. Tim. and the Plato Arabus series. Furthermore, I will argue that, besides his own disciplinary concerns, Klibansky's cognizance of the protectionist attitude of many of his British colleagues prompted him to modify Kraus and Walzer's formulation of Plato Arabus - its components and contributors.

I have structured the article in three sections, of which the first treats Kraus and Walzer's collaboration prior to Klibansky's involvement, the second considers the reconceptualization of their edition under Klibansky's direction and its place in the Plato Arabus scheme, and the last sketches their individual contributions to the volume. This arrangement is roughly chronological; the latter two sections, however, cover overlapping events in 1936-7. The appendix to this paper gives a timeline of the phases of as well as episodes relating to the composition of the editio princeps. The conclusion returns to the subject of reception by reflecting on how Klibansky's agenda for Plato Arabus, which sought to highlight "commentaries of an earlier stage of... philosophical development, less speculative and closer to the [Platonic] text," may account for many current scholars' philosophical disinterest in Galen's Com. Tim. ${ }^{10}$

\section{COM. TIM. “HIERZULAND,” 1934-5}

The first reference in print to the surviving Arabic version of Com. Tim. appears in a report submitted by the classicist Eduard Norden (1868-1941) to the Prussian Academy of Sciences on 26 July 1934 on behalf of Hellmut Ritter (1892-1971) and Richard Walzer. ${ }^{11}$ The two

${ }^{10}$ Raymond Klibansky, The continuity of the Platonic tradition during the Middle Ages (London, 1939), 15 [my addition].

${ }^{11}$ See Helmutt Ritter and Richard Walzer, "Arabische Übersetzungen griechischer Ärtze in Stambuler Bibliothek," Sitzungsberichte der Preussischen Akademie der 
had prepared a catalog of Istanbul manuscripts of Arabic translations of Greek medical works, in which they describe the principal witnesses to Galen's Platonic synopsis (MSS Ayasofya 2410 and Es ${ }^{c}$ ad Efendi 1933). ${ }^{12}$ Both were absent from the academy's annual meeting as they had been effectively banished from German academia: Ritter had lost his chair in Oriental Studies at the University of Hamburg in 1926 after being convicted and jailed the previous year for homosexuality, whereas the notorious "Aryan-paragraph" of the "Law for the restoration of the professional civil service" (7 April 1933), which forbade persons of Jewish heritage from holding appointments in public institutions such as universities, had forced Walzer from his position as Privatdozent in Classical Philology at the University of Berlin in October 1933. ${ }^{13}$ A footnote in their entry on Com. Tim. announces Walzer's plans to edit the text, as if they were already under way: "an edition is being prepared by R. Walzer" (Ausgabe wird von R. Walzer vorbereitet, [my emphasis]). ${ }^{14}$ There is no acknowledgment of Kraus' involvement at this point in time.

The lost Com. Tim. seems to have been Ritter's rather than Walzer's discovery. Occupied with his research on the poet Nizāmī and technical treatises in Arabic and Persian, Ritter may have invited his younger colleague to take on the editorial task, which demanded more advanced philological skills than the budding Arabist perhaps possessed then. ${ }^{15}$

Wissenschaften. Philosophisch-Historische Klasse (Berlin, 1934), 800-846. Norden is listed as a character reference on Walzer's application to the SPSL (MS SPSL 297/1-3, fol. 1).

12 See Ritter and Walzer, "Arabische Übersetzungen,” p. 818, no. 32. In addition to MSS Ayasofya 2410 and $\mathrm{Es}^{\mathrm{c}}$ ad Efendi 1933, Kraus and Walzer (Compendium Timaei, p. 32 [Arabic]) utilized a fragment in a Berlin MS (Ahlwardt 5031, fol. 84a-85a) to establish the Arabic text of Com. Tim.

${ }^{13}$ From 1871-1994, Paragraph 175 of the German Criminal Code made homosexual acts between "persons of the male sex" punishable by imprisonment. On Ritter's conviction, see Josef van Ess, "Ritter, Hellmut," in Ehsan Yarshater (ed.), Encyclopaedia Iranica, online edition (New York, 1996-). On German academics' minimal opposition to the "Law for the restoration of the professional civil service," which defined "non-Aryan" as an individual with at least one Jewish parent or grandparent, see Robert P. Ericksen, Complicity in the holocaust: Churches and universities in Nazi Germany (Cambridge, 2012), 61-93. The SPLS required its Jewish applicants to self-identify as either "Jewish Orthodox" (Orthodox jüdisch) or "Jewish reformed" (Liberal jüdisch) and report the grounds and dates of their dismissal. Walzer wrote $j a$ next to "Jewish reformed" and indicated that he had already lost his position as a research assistant (May 1933) before his dismissal in October.

${ }^{14}$ Ritter and Walzer, "Arabische Übersetzungen," p. 818, n. 4.

${ }^{15}$ In 1934, Ritter had published with the Czech Iranologist Jan Rypka (1886-1968) a 
The preface to their catalog declares that Ritter "found" (besorgte) the manuscripts, which Walzer inspected with a fresh pair of eyes during a trip to Istanbul in August and September 1933. ${ }^{16}$ With the help of local informants and German funding, Ritter had been surveying since his dismissal from Hamburg the manuscript holdings of the various libraries of Istanbul to revise the faulty catalog on which key reference works, such as Brockelmann's Geschichte der arabischen Litteratur, had relied. ${ }^{17}$ Through this research, Ritter had become, as Walzer would later put it, "the king of these libraries in his own right and at the same time a kind of proconsul for oriental scholars all over the world."18 Gotthelf Bergsträsser (1886-1933), the editor of Hunayn ibn Ishāq's (d. ca. 873/7) famous Galen "Epistle" (Risāla), may have introduced the pair, for he was Ritter's friend and had inspired Walzer to pursue the "Arabic fortunes of Galen" when he began to learn Arabic under him in 1932. ${ }^{19}$

Franz Rosenthal (1914-2003), a future collaborator on Plato Arabus, remarks that Walzer's change of interest came rather late in his academic career: "in spite of being already in his thirties [he] was new at Arabic" - Walzer claims that he was actually twenty-eight. ${ }^{20}$ While in Berlin, Walzer does not appear to have developed a reputation for expertise in Arabic, a situation to which Rosenthal calls attention when

critical edition of Nizāmī’s last romance Seven portraits (Heft Peiker. Ein romantische Epos des Nizāmī Genğe ${ }^{j} i$, ed. Hellmut Ritter and Jan Rypka [Prague, 1934]); in the following year, he edited with several collaborators a fourteenth-century Persian description of the technique to produce faience ceramics (Hellmut Ritter, Friedrich Sarre, Julius Ruska, and Rudolf Winderlich, Orientalische Steinbücher und persische Fayencetechnik [Istanbul, 1935]).

${ }^{16}$ Ritter and Walzer, "Arabische Übersetzungen," p. 803.

17 On Ritter's first stay in Istanbul, see Thomas Lier, "Hellmut Ritter in Istanbul 19261949," Die Welt des Islams, vol. 38 no. 3 (1998), 334-85. Ritter's doctoral supervisor Carl Heinrich Becker (1876-1933), who served as Minister for Culture in Prussia from 1925-1930, probably helped him to secure funding for this residency on the grounds that it could serve German interests. As Suzanne Marchand (German orientalism in the age of Empire [Washington, DC, 2008], p. 361-7, 458) explains, Becker planned to extend German influence over Turkey (and Africa) through Kulturpolitik, which consisted of not only establishing "cultural stations like missions and schools" but also acquiring knowledge about the Islamic world.

${ }^{18}$ Richard Walzer, "Hellmut Ritter: 27.2.1892 - 19.5.1971," Oriens, 23/24 (1974), 1-6, on p. 4.

${ }^{19}$ See Walzer, "Hellmut Ritter," p. 2; id., "Formation of a scholar," p. 163; "Richard Rudolf Walzer (1900-1975)," Les études philosophiques, no. 1 (1976), 119-123, on p. 119.

${ }^{20}$ Hinrich Biesterfeldt (ed.), "Franz Rosenthal's Half an autobiography," Die Welt des Islams, vol. 54, no. 1 (2014), 34-105, on p. 56. Cf. Walzer, "Formation of a scholar," p. 163. 
alleging that the older scholar "did not influence [his own] interest in things Graeco-Arabic." 21 As a letter from Paul Kraus establishes, dated to six months after the publication of the Istanbul catalog (27 January 1935), Walzer seems to have made contacts among the orientalists of Berlin, at least, before moving to Cambridge and Rome, where he held a lectureship in Greek philosophy from 1935 until Italy's passage of its first round of anti-Jewish legislation in the autumn of $1938 .{ }^{22}$ In this holograph note, Kraus solicits Walzer's thoughts about approaching Alfred Pohl (1890-1961) at Orientalia, which had previously accepted his text and French translation of philosophical works by Abū Bakr al-Rāzī, about submitting their edition of Com. Tim. to the journal for consideration. $^{23}$

The brief message does not disclose what progress, if any, they had made on their edition of Galen's abridgement. Walzer's autobiographical comment to the Oxford Near East History Group that, while in Berlin, he had formulated plans for "common work" with Kraus seems to place the start of their collaboration prior to the announcement of his preparation of the edition in the 1934 report to the Prussian Academy of Sciences. ${ }^{24}$ Kraus had left his positions at the University of Berlin and traveled to Paris in April 1933 when word reached him that Jews were being fired from the Institut für Geschichte der Medizin und Naturwissenschaften, where he was working as a research assistant to the historian of science Julius Ruska (1867-1949). ${ }^{25}$ Therefore, chronologically, it makes sense

21 "Franz Rosenthal," p. 56.

22 See Walzer, "Formation of a scholar," p. 165-6; Luc Deitz, "Walzer, Richard Rudolph (1900-1975), classical scholar and orientalist," in Lawrence Goldman (ed.), Oxford dictionary of national biography (Oxford, 2004), online. On the Italian Racial Laws' exclusion of Jews from universities and learned societies, see Annalisa Capristo, "The exclusion of Jews from Italian academies" and Roberto Finzi, "The damage to Italian culture: The fate of Jewish university professors in fascist Italy and after, 1938-1946," in Joshua D. Zimmerman (ed.), Jews in Italy under fascist and Nazi rule, 1922-1945 (Cambridge, 2005), 81-95 and 96-113.

${ }^{23}$ ARC. $4 * 1656 / 111$ (N. B. the folios are unnumbered in the Walzer Archive). See Paul Kraus, "Raziana I," Orientalia, 4 (1935), 300-334, and "Raziana II," Orientalia, 5 (1936), 35-56. Kraus and Pohl appear to have been acquainted with each other since their time in Berlin, where they studied Assyriology under the same doctoral supervisor, Bruno Meissner (1868-1947) (see Kraemer, "The death of an orientalist," p. 184).

${ }^{24}$ Richard Walzer, "Formation of a scholar," p. 165.

${ }^{25}$ Kraemer, "The death of an orientalist," p. 187. Although Kraus also held an appointment as a Privatdozent in Semitic Languages and Culture at the University of Berlin, his SPSL application registers only his official dismissal from his research assistantship on 3 April 1933 for being "non-Aryan" (see MS SPSL 513/1-4, fol. 11). 
if Walzer first broached the subject of Com. Tim. with Kraus before he had personally examined the manuscripts in Istanbul later that year (August and September 1933), when he may have had access to Ritter's preliminary descriptions of the texts and photostats. Although Walzer takes credit in the Istanbul catalog for the inception of the edition of Com. Tim., the documents in his archive from 1935 show Kraus as the driving force behind its development.

Three other letters from Kraus, dispatched over the remaining course of 1935, portray Walzer as having an editorial instead of authorial role: he reviewed the content that Kraus created. On 15 March 1935, Kraus writes to Walzer at a Cambridge address to ask for the return of his manuscript of the Arabic text, because he has "so many textual critical nuts to crack" (so viele textkritische Nüsse darin zu knacken) and a "provisional translation" (vorläufige Uebersetzung) to compose before they submit everything to Pohl by 20-25 September for the publication of the first half of their edition in January $1936 .^{26}$ The drafting of Com. Tim. must not have been that advanced, for Kraus sends to Walzer, still in Cambridge, on 4 September 1935 "the second third of the Timaeus," including his translation and notes stemming from a comparison of the Arabic with Plato's Greek. ${ }^{27}$ Kraus may have revised his Arabic text so significantly in the intervening period to warrant another review by Walzer, but, in the absence of draft copies of the Arabic portion of the edition, this theory remains conjectural. Nonetheless, Kraus' concern in this exchange is with the clarity of the notes, which he asks his partner to "work through" (durcharbeiten); to assist Walzer in locating the passages in his translation that he has prioritized for commentary, he remarks that he has underlined in red "words or sentences where the Arabic translator has read our Timaeus text but mangled it" (Worte oder Sätze, wo der arabische Uebersetzer zwar unseren Timaeustext gelesen, aber daneben gehauen hat) and in blue Galen's additions. ${ }^{28}$

Kraus self-identifies as "Orthodox Jewish / orthodox jüdisch" on his application (MS SPSL 513/1-4, fol. 12). As Kraemer ("The death of an orientalist," p. 183-4) relates, before his move to Berlin in 1927, Kraus had spent a year on a kibbutz in Palestine (1925); increasingly disillusioned with Zionism, he left to take classes at the Hebrew University in Jerusalem.

${ }^{26}$ ARC. $4 * 1656 / 111$. According to his SPSL application (MS SPSL 297/1-3, fols. 2, 32), Walzer had received a stipend from the Faculty of Classics to fund his initial stay in Cambridge from October 1933-4 and had been awarded a research grant in 1935 to extend the trip, which he turned down for the lectureship in Rome.

27 ARC. $4 * 1656 / 111$.

28 These sentences in the letter are underlined in red and blue, respectively. 
The language of the translation was a point of contention between the collaborators. Kraus refers opaquely in the September correspondence to his "obvious reasons" (naheliegenden Gründen) for rendering the text into French that may relate to his previous use of the language in his publications with Orientalia or new academic life in Paris. Conscious of being a non-native speaker, Kraus assures Walzer that he will have a French acquaintance read over the translation before it goes to print. A letter delivered two months later (22 November 1935) - during which their submission deadline had passed and been reset to January 1936 - exposes that Walzer had pressed for the translation to be in German. ${ }^{29}$ Kraus does not respond to (and thus reveal) Walzer's rationale, but answers that, while he does not want to be a "stickler for principles as language politics are beyond [him]" (will ich nicht Prinzipienreiter sein, da mir an sich Sprachpolitik fernliegt), his colleague's "stance is not right" (Ihren Standpunkt nicht als richtig). In line with the nationalistic policies of the National Socialist Party, many German scholars began to insist on the utilization of German as the language of scientific discourse both inside and outside of Germany. ${ }^{30}$ Walzer perhaps realized that, to maintain any standing in what had been his academic home since his youth, he had to compose his work in German to ensure its circulation. Moreover, it is worth noting that, unlike Kraus who had a network of patrons and friends in Paris, Walzer was reliant on mostly German referees in his search for a stable job, which saw him uproot his family twice in $1934-5{ }^{31}$

A letter from the following autumn (3 October 1936), in which Kraus lists a French and German translation among the documents in his "Timaeus Dossier," confirms that he did acquiesce to Walzer's request. ${ }^{32}$ While the exigencies of the two scholars' employment situations may un-

29 ARC. 4* 1656/55.

${ }^{30}$ Ericksen (Complicity in the holocaust, p. 90) offers a conspicuous case of Sprachpoli$t i k$ : in response to the decision to hold the 1933 annual German historical conference in the disputed territory of Upper East Silesia, which the Treaty of Versailles had ceded to Poland after WWI, a large portion of the German contingent demanded not only that they have the right to present in German but also that their Polish counterparts be banned from presenting in Polish at the meeting and be required to deliver a minimum number of papers in German.

31 Walzer's German referees, several of whom also fled Germany to escape anti-Jewish persecution, include Werner Jaeger, Eduard Norden, Hans Heinrich Schaeder, Ernst Cassirer, Eduard Fraenkel, Helmutt Ritter, and Otto Regenbogen (see MS SPSL 297/1-3, fol. 1). For Kraus' time in Paris, see Kraemer, "The death of an orientalist," p. 187-95.

32 ARC. $4^{*} 1656 / 55$. 
derlie their differing opinions about the target language and readership of the translation, both attempted to enhance their academic profiles by expanding the project. Kraus seems to have planned a more ambitious introduction to the edition that would cover other Platonic sources in Arabic such as al-Fārābī's paraphrase (talhĭs $)$ of the Laws, which, as the November 1935 missive relays, he was editing (bearbeiten) with Leo Strauss. ${ }^{33}$ He abandoned the idea for a more expansive introduction because the originality of al-Fārābī's output (ein ganz originale Leistung des Farabi) contrasted too sharply with Galen's text. ${ }^{34}$

Kraus' enthusiastic description of al-Fārābī's exegesis may represent a subtle appeal to Walzer to include the text in the Plato Arabus program, the direction of which he had assumed as early as the beginning of that November. As will be seen, Walzer would propose a co-edited volume on al-Fārābīs Laws by Kraus and Strauss to Klibansky, who did not mince his words about the collaboration. ${ }^{35}$ Despite shouldering most of the workload on Com. Tim., Kraus is markedly absent from the two men's conversations about approaching the edition as a springboard for the Arabic section of the Corpus Platonicum, which Klibansky asked Walzer to edit on 7 July $1935 .{ }^{36}$ This first letter from Klibansky does not mention Galen's summary but outlines his aim for Plato Arabus: the series should make Arabic versions of lost Greek originals accessible to non-readers of Arabic through either Latin or English translations. Com. Tim. becomes a point of interest for Klibansky in his discussions with Walzer about securing funds toward the $£ 1000$ cost of the three-year project, which the director of the Warburg Institute Fritz Saxl (1890-1948) had priced. ${ }^{37}$ In an exchange from 11 November 1935, which

${ }^{33}$ Kraus met Strauss in Berlin, probably when he began to direct the doctoral dissertation of Strauss' sister Bettina on Šānāq's "Book on poisons and theriac" (Kitāb al-Š̄aña fi l-sumūm wa l-tiryāq), a Sanskrit work supposedly translated into Arabic under the reign of Hārūn al-Rašīd (766-785). Kraus and Bettina would marry in Cairo in 1936. On Krauss' relationship to the Strauss siblings, see Kraemer, "The death of an orientalist," p. 198-9.

${ }^{34}$ Kraus writes, "My hunch, that this paraphrase should not be compared with Galen's and therefore need not be considered in our introduction to the Timaeus, has been substantiated" (Meine Vermutung, dass diese Paraphrase nicht mit der des Galen auf eine Stufe zu setzen ist und daher in unserer Einleitung zum Timaeus nicht berücksichtigt werden braucht, hat sich bestätigt).

35 See p. 239 below.

${ }^{36}$ See ARC. $4^{*} 1656 / 458$. The letter indicates that Klibansky, who was an assistant lecturer at King's College, London from 1934-5 following his dismissal from Heidelberg University on 18 August 1933 (see MS SPSL 316/1-4, fol. 234-6), had raised the editorial opportunity to Walzer in person sometime earlier (von dem ich Ihnen seinerzeit gesprochen habe). 
merits quoting at length, Klibansky frames his request that Walzer pull his edition from Orientalia as career advice:

My personal impression is that it might be favorable for you if you could reserve your edition of the Arabic version of Galen's paraphrase of the Timaeus for your "Plato Arabus." A first edition of the entire text could do more for you in this country than a reworking of an edition published in Orientalia. However, this is purely a personal impression - a consideration that has little to do with the matter itself. I am naturally delighted to see the text published as soon as possible. The danger of splitting up the text - which undoubtedly is a given when publishing in journals - is offset by the fact that a second editing [sc. in Plato Arabus] can bring some improvements and additions. ${ }^{38}$

Emphasizing twice that the above remarks are only his "personal impression" (persönlicher Eindruck), Klibansky leaves Walzer to imagine how he might benefit "in this country" (hierzuland) from reserving Com. Tim. for a British publication. In his previous message, Klibansky had made a point of communicating the positive reaction of Sir David Ross (1877-1971), who as provost of Oriel College had helped him to find employment in Oxford (and would later do the same for Walzer), to the prospect of Walzer joining the editorial team of the Corpus Platonicum. ${ }^{39}$

${ }^{37}$ ARC. $4^{*} 1656 / 458$. Saxl requested the sum of $£ 1000$ - roughly $£ 50,662.60$ in today's money (value reached by using www.nationalarchives.gov.uk/currency-converter/) - from the SPSL in June 1936. Both students of Aby Warburg, Klibansky and Saxl were involved in the transfer of the Kulturwissenschaftliche Bibliothek Warburg from Hamburg to London, starting in December 1933.

${ }^{38}$ Mein persönlicher Eindruck ist, dass es für Sie günstig sein könnte, wenn Sie Ihre Edition der arabischen Version der Galen-Paraphrase zum Timaios für Ihren "Plato Arabus" reservieren könnten. Eine Erstedition des gesamten Textes könnte Ihnen hierzuland mehr zustatten kommen als die Neubearbeitung einer in den "Orientalia” erschienenen Edition. Doch die ist ein rein persönlicher Eindruck, - eine Erwägung, die mit der Sache selbst wenig zu tun hat. Ich fre<ue> mich näturlich, den Text sobald als möglich veröffentlicht zu sehen. Die Gefahr der Zersplitterung der Texte - die durch Publikation in Zeitschfriften zweifellos gegeben ist - wird dadurch wettgemacht, dass die zweite Bearbeitung unter Umständen einige Besserungen und Zufügungen bringen kann.

${ }^{39}$ Before his lectureship at Oriel (1936-1946), Klibansky had enjoyed senior common room rights at the invitation of Ross. For Klibansky's warm reception in Oxford, see Graham Whitaker, "Philosophy in exile: The contrasting experiences of Ernst Cassirer and Raymond Klibansky in Oxford," in Sally Crawford, Katharina Ulmschneider, and Jaś Elsner (ed.), Ark of civilization: Refugee scholars and Oxford University (Oxford, 2017), 341-59. Walzer had written his doctoral thesis on Aristotle (Magna Moralia und Aristotelische Ethik, 1929), so the attention of the foremost authority on Aristotle would have been flattering, as Klibansky appears to have judged. During WWII, Ross deputized Walzer to deliver philosophy lectures in his stead while he traveled to China in his capacity as president of the British Academy to strengthen 
Saxl took a more forthright approach to persuading Walzer to save the editio princeps of Com. Tim. for Plato Arabus, by linking the series' financial viability to his decision. His letter on 13 December 1935 reiterated with added urgency Kliblansky's earlier plea for a definitive list of texts and contributors, including what Walzer himself would prepare. ${ }^{40}$ Since Klibansky and Walzer's November correspondence, Saxl had become aware of the 1934 publication of Arabic fragments of Galen's commentary on the Timaeus through the Corpus medicorum Graecorum. ${ }^{41}$ The art historian had not conflated Galen's two explanations of the dialogue - namely, the commentary "On the medical statements in Plato's Timaeus" and Com. Tim. - but appears to have invoked the example of the former exegesis to convey to Walzer the risk that these external publications of "Platonica arabica" posed to the fundability of their own program. He warns, "the longer we wait to present the plan the greater the risk is that the pieces to be included in Plato Arabus will be scattered, published by classical philologists or Arabists, and the willingness to fund Plato Arabus will be reduced on the part of the concerned agencies." 42 Novelty, in Saxl's view, is their project's selling point. The subtext to the message is that, if Walzer offers Com. Tim. to Orientalia, he will diminish even further their research monopoly on Arabic Platonism and therefore claim to originality.

Walzer did not capitulate until the following June, when he had been promised financial compensation for his labor (£250), the receipt of which was contingent on him withdrawing the edition from the journal. ${ }^{43}$ Meanwhile, he had informed Kraus - who, as the corresponding author, was responsible for contacting Orientalia about their withdrawal - of his negotiations with the Warburg. ${ }^{44}$ The next section will show that Kraus was supportive of Plato Arabus - even of the eventual

ties with Chinese academics.

40 ARC. $4^{*} 1656 / 458$.

${ }^{41}$ Galeni In Platonis Timaeum commentarii fragmenta, appendicem arabicam addidit Paulus Kahle, ed. Heinrich Otto Schröder (Leipzig and Berlin, 1934).

42 Je länger wir mit dem Vorlegen des Planes warten, desto grosser ist die Gefahr, dass die Stücke, die in den "Plato Arabus" einbezogen werden sollen, von klassischphilologischer oder arabisticher Seite verstreut publiziert werden, und auf diese Weise die etwaige Bereitschaft, einen "Plato Arabus" zu finanzieren auf Seiten der in Betracht kommenden Stellen gemindert wird.

${ }^{43}$ Saxl writes to Walzer on 12 June 1936 (ARC. $4^{*} 1656 / 458$ ) that it would be "inappropriate" (unzweckmässig) for the edition to appear in Orientalia after the British Academy and Union Académique Internationale had accepted their funding proposal.

${ }^{44}$ See Kraus' letter dated to 23 July 1936 (ARC. $4^{*}$ 1656/111). 
choice of Latin as its language of translation, which, in his opinion, solved any Sprachschwierigkeit - because it provided an outlet for him to go beyond what he had hoped to achieve in the edition's introduction: to trace the philosophical, medical, and alchemical strands constitutive of Platonism in the medieval "Orient." ${ }^{45}$ This more wide-ranging vision put Kraus into conflict with Walzer and Klibansky, who, as I will now recount, would discuss among themselves the priorities of the program and Kraus' role in realizing them.

\section{PLATO ORIENTALIS, 1936-7}

Only a fraction of the Plato Arabus program that Klibansky advertised in his prefatory essay Continuity of the Platonic tradition (1939) made it to print. The conspectus divided the series into six subsections: (1) "Platonica," covering manuscripts and Platonic quotations; (2) "paraphrastic and original writings," encompassing al-Fārābī's and Ibn Rušd's summaries of the Laws and Republic, respectively, in addition to the former's "Philosophy of Plato and Aristotle;" (3) "translations of Greek writings," namely the remnants of Galen's Platonic synopses and Theon of Smyrna's treatise on the reading order of Plato's dialogues; (4) "Platonic vitae and dicta;" (5) "Plato pseudepigraphus," composed of a "Plato alchymista" and "magus;" and (6) "recastings of Neoplatonic works" ("Theology of Aristotle" and "Book of causes"). ${ }^{46}$ Klibansky envisioned the constituent texts of Plato Arabus as belonging to the "main stream of [the Platonic] tradition," into and from which the "subsidiary currents" of their Syriac and Hebrew renditions flowed. ${ }^{47}$ What the publication glosses over but comes to the fore in Klibansky's correspondence with Walzer is that he imagined Plato Arabus itself to be a tributary - to extend his river analogy - of Plato Latinus. From his doctoral study of Nicholas of Cusa (1401-1464), Klibansky had developed an interest in the Platonic holdings of his and other Latin humanists' personal libraries. ${ }^{48}$ His ambition to understand the

45 For Kraus' approval of Latin as the language of translation, see his letter on 24 June 1936 (ARC. $4^{*}$ 1656/111).

${ }^{46}$ Klibansky, Continuity of the Platonic tradition, p. 53-4.

47 Ibid., p. 18.

${ }^{48}$ For the origin of the Corpus Platonicum in Klibanksy's dissertation, see Georges Leroux, "Raymond Klibansky and the Corpus Platonic Medii Aevi: A discussion of the Plato Latinus Series," in Philippe Despoix and Jillian Tomm (ed.), Raymond Klibansky and the Warburg Library network: Intellectual peregrinations from Hamburg to London and Montreal (Montreal, 2018), 160-81, on p. 165. 
intellectual context of Latin humanism through a source critical lens would dictate the research agenda of Plato Arabus, as a letter from 4 September 1936 demonstrates. There, Klibansky stipulates that each contributor had to address in their volume's introduction "whether and in what form the [Arabic] text was accessible in the Latin Middle Ages" (ob und in welcher Form der Text dem lateinischen Mittelalter zugänglich war). ${ }^{49}$

Furthermore, the conspectus represents an uneven compromise that extracts Kraus' suggestions from his proposal for a stand-alone series _ "Plato Orientalis" - in the service of Klibansky's research goals. The Plato Arabus conspectus took shape soon after Saxl's request in December 1935 for Walzer to concretize his plan for the project in preparation for their funding applications. In the first month of the new year (21 January 1936), Klibansky submitted to Walzer a draft that arranged the texts earmarked for the series, including titles familiar (e.g., Com. Tim. and al-Fārābì's Laws) and unfamiliar (e.g., "Theology of Aristotle," De pomo and De vacca) from their correspondence, into many of the same subsections that would later appear in print - he also defended the Latinity of the name "Plato Arabus" over the more grammatical alternative "Plato Arab." 50 While Klibansky's unpicking of the scheme in his next exchange with Walzer (12 February 1936) shows that it did not have his full approval, he concentrates in this letter on conveying his unease about the makeup of the contributors. ${ }^{51}$ Klibansky not only criticizes Leo Strauss' involvement due to his poor knowledge of Greek and no demonstrable skill in Arabic philology but also bemoans the absence of young English participants. ${ }^{52}$ Despite the flaws in the training of his hoped-for

49 See ARC. $4 * 1656 / 458$.

${ }^{50}$ Ibid. Concerning the series name, Klibansky adds in his handwritten postscript that he prefers the "less classical... poetic form" (weniger klassische... poetische Form) over the "ugly sounding" (unschön klingt) Plato Arab. The Latinity of the title seems to have been a point of controversy between the two, for Klibansky repeats the same arguments in a letter to Walzer six months later (21 July 1936).

${ }^{51}$ Klibansky's message in February argues against the inclusion of De pomo and De vacca because the former is pseudo-Aristotelian - it does not feature Socrates, as Walzer misremembers - and the latter for reasons of space should belong with the Latin pseudepigrapha. See ARC. $4 * 1656 / 458$.

${ }^{52}$ About Strauss, Klibansky remarks, "Whether Mr. Strauss' philological skills are sufficient for [producing] the critical edition of an Arabic text, I cannot judge; his knowledge of Greek seems weak to me" (Ob die philologischen Fähigkeiten des Hern Strauss zur kritischen Edition eines arabischen Textes ausreichen, kann ich nicht beurteilen; seine Griechisch-Kenntnisse scheinen mir dürftig). In another letter (undated), Klibansky advises Walzer to test Strauss' knowledge and philological skills 
English recruits (specifically, in paleography), Klibansky's response in the autumn of 1936 to Kraus' push to expand the project highlights that he had political reasons for trivializing them.

Over the summer (24 June 1936), Kraus had contacted Walzer, permitting him to share his message with the Warburg, about his issues with the title "Plato Arabus." 53 The series' name, in his opinion, bespoke a focus on Arabic literature to the exclusion of Syriac and Hebrew, of which the former they "could not ignore" (darf... nicht ignorieren) if they were to treat vitae and logical works. He preferred "Plato Orientalis" for its capacious significance. Klibansky integrated into the final conspectus several recommendations from Kraus' letter, such as the addition of a "Plato Arabus Alchimista" and his identification of historical authors as sources for Platonic quotations; he cited, however, English scholars' predilection for projects of limited scope to excuse his reduction of "Plato Syrus" and "Hebraeus" to appendices. ${ }^{54}$ As further justification, he explained to Walzer that the Hebrew section was dispensable because it derives from the Arabic (dass der hebräische Platon, dadurch, dass er auf dem arabischen Platon zurückgeht), while restrictions on space necessitated their avoidance of overlaps with Baumstark's Geschichte der syrischen Literatur (1922).

Klibansky's aforementioned correspondence from 4 September 1936 reveals that his preconception of the tastes of a segment of English academia - the heads of the British Academy, who had, nonetheless, an outsized role in determining the direction of scholarship in the country informed his design of Plato Arabus. Interpreting the British Academy's mission to fund British research as a nativist commitment to promoting the scholarship of the English-born, Klibansky urged Walzer to expand the list of contributors beyond German and Italian Jews. He advised,

The British Academy naturally attaches great importance to the collaboration of English scholars. So, we must see how to augment the current list if possible, so that tam quod ad confessiones quam quod ad nationes ["so with

(dessen sprachliche Kenntnisse und philologische Fähigkeiten Sie gewiss prüfen werden). Cf. Kraus' claim that Strauss' command of "scholastic Latin" was so strong that he could versify and speak it as well as translate into it. See ARC. $4^{*} 1656 / 111$.

53 See ARC. $4 * 1656 / 111$.

${ }^{54}$ On 21 July 1936, Klibansky maintains, "a strict limitation of the scope is favourable to English scholars" (den englischen Gelehrten gegenüber eine straffe Beschränkung des Umfangs günstig); see ARC. $4 * 1656 / 458$. The "Platonica" subsection in the printed conspectus (Klibansky, Continuity of the Platonic tradition, p. 53) covers collections of Platonic quotations from philosophers, scientists, and historians. In his June missive, Kraus also lists potential texts for each section, such as Kitāb alrawābi $\bar{\imath}^{c}$ and Ğābir's Kitāb musahhạat Aflāțūn for "Plato Arabus Alchimista." 
regard to religions as with regard to nations"] a greater variatio be introduced besides Mr. Kraus, Strauss, [Erwin] Rosenthal, [Franz] Rosenthal, Levi della Vida, Teicher, and whomever else [from] Italy might come into consideration. The scholars [should] also [be] Englishmen [who] contribute and if possible be in a prominent position. If the researchers proposed by us are really the foremost specialists in their field[s], they must, of course, be consulted under all circumstances, regardless of other considerations. However, if there were equivalent English researchers, they would have to be won over for collaboration first in rank. ${ }^{55}$

One of only six Jewish humanists who found stable employment in Oxford in the 1930s, Klibansky was acutely aware of how the pervasive presence of anti-Semitism in British academia influenced the distribution of support. ${ }^{56}$ Klibansky reckoned that the participation of eminent English orientalists such as Arthur John Arberry (1905-1969), whom he later lobbied Walzer to include on the program, would help to insulate the project against criticism for its expenditure of British money on foreigners, especially in the context of an unprecedented economic slump. ${ }^{57}$ The framing of the Corpus Platonicum as an intellectual history of the "Western world" - as a draft prospectus from 1936 puts it - may also have done similar conciliatory work in appealing to the sentiments of an academic audience openly hostile to the "Semitic."58

Saxl had also intervened to invite another scholar with significant

55 Die British Academy legt naturgemäss auf die Mitarbeit von englischen Gelehrten grossen Wert. So müssen wir sehen, die jetzige nach Möglichkeit Liste so zu ergänzen, dass tam quod ad confessiones quam quod ad nationes eine grössere "variatio" eintritt und ausser den Herren Kraus, Strauss, Rosenthal, Rosenthal, Levi della Vida, Teicher und den etwa in Frage kommenden anderen italien. Gelehrten auch [Gelehrte anderer is struck out] Engländer mitwirken und zwar möglichst an sichtbarer Stelle. Falls die von uns vorgeschlagen Forscher wirklich die ersten Spezialisten auf ihrem Gebiet sind, müssen sie natürlich unter allen Umständen, ungeachtet aller sonstigen Rücksichten, herangezogen werden. Sollte es aber gleichwertige englische Forscher geben, so müssten diese in erster Linie zur Mitarbeit gewonnen werden.

${ }^{56}$ On anti-Semitism in 1930s Oxford, see Laurence Brockliss, "Welcoming and supporting refugee scholars: The role of Oxford's colleges," in Sally Crawford, Katharina Ulmschneider, and Jaś Elsner (ed.), Ark of civilization: Refugee scholars and Oxford University, 1930-1945 (Oxford, 2017), 62-76.

${ }^{57}$ Klibansky sent two letters in February 1937 (on the 2nd and 15th) that reveal Arberry's dissatisfaction with Kraus and Walzer's appropriation "of the lion's share of the work [on Plato Arabus] between them." Arberry was unhappy that he was not offered the opportunity to edit an Arabic version of a lost Greek text. See ARC. $4^{*}$ $1656 / 458$.

58 The draft prospectus appears in a letter from Saxl (28 December 1936); Klibansky, however, is its probable author because it contains many of the same phrases that would later appear in the Continuity of the Platonic tradition. Whereas Saxl's missive writes, "If the Platonic tradition of the Western world [Western Europe is struck 
ties to British academia, Anneliese Gottschalk-Baur (d. 1973), to contribute. $^{59}$ A refugee of Nazi persecution, Gottschalk-Baur had been awarded a three-year fellowship at Newnham College, Cambridge for a project on the "Platonic Tradition in Islam," which was already investigating the prospective domain of Plato Arabus, as she informed Walzer on 9 August $1936 .{ }^{60}$ Saxl strategized with Walzer about how Gottschalk-Baur's involvement would obviate the need to account for their encroachment on the territory of a funded researcher so well regarded in Cambridge (Sie macht menschlich einen vorzüglichen Eindruck und ist in Cambridge sehr Freundlich aufgenommen worden). ${ }^{61}$ Notwithstanding Gottschalk-Baur's good repute at the sort of English institution from which Klibansky had wished to recruit, his curt replies to her inquiries about practical aspects of the program (e. g., the identity of the editorial committee) betrays his lack of enthusiasm for her participation. ${ }^{62}$ Kraus was more pointed in dismissing her as "so horribly clueless" (so entsetzlich ahnungslos). ${ }^{63}$ Gottschalk-Baur's name appears on an undated conspectus by Walzer without the assignment of a text; she queried this oversight (in writing and in person) with both Saxl and Klibansky at the start of 1937, after which she drops out of all Plato Arabus correspondence. ${ }^{64}$

Walzer's request in autumn 1936 to speak with Klibansky about re-

out] is to be understood, three main currents, the Latin, the Byzantine, and the Arabic, have to be taken into account," Klibansky's published text reads "If the Platonic tradition of the Middle Ages a whole [my emphasis] is to be understood" etc. Cf. ARC. $4^{*}$ 1656/458, and Klibansky, Continuity of the Platonic tradition, p. 13.

${ }^{59}$ Saxl, Klibansky, and Kraus all refer to her as "Frau Gottschalk" in their correspondence. Gottschalk's first name appears variously in print as Annelise and AnnaLuise.

${ }^{60}$ After her time in Cambridge, Gottschalk-Baur worked in the Mingana Collection at the University of Birmingham with her husband, the Arabist Hans Ludwig Gottschalk (1904-1981).

${ }^{61}$ See Saxl's 24 July 1936 letter in ARC. $4 * 1656 / 458$.

62 Klibansky reports to Walzer (on 11 February 1937) that her questions about the contributors of Plato Arabus and reimbursement for the costs of manuscript reproductions made an "unpleasant impression" on him (die mir einen wenig erfreulichen Eindruck machte). See ARC. $4 * 1656 / 458$.

${ }^{63}$ See ARC. $4 * 1656 / 111$. Walzer seems to have been hesitant about Gottschalk-Baur as well, for he writes in the margin to Saxl's letter that "she has to know Arabic very well" (muss sie kennen sehr gut arabisch).

${ }^{64}$ A letter from Saxl on 25 January 1937 to Walzer mentions his meeting with Gottschalk-Baur in London about editorial assignments; see ARC. 4* 1656/458. In Klibansky's 11 February 1937 missive, he also raises with Walzer the need to find editorial work for Gottschalk-Baur. To my knowledge, Gottschalk-Baur never published her findings from the Cambridge project. 
versing his own decision to grant Kraus equal partnership in editing Plato Arabus indicates that this interference from the Warburg may have created tension between the two. While Klibansky speculates in his written response that interpersonal differences and money are behind the conflict, his limitation of the project appears to have prompted Kraus to distance himself from the undertaking. ${ }^{65}$ About two weeks after Walzer received Klibansky's brief about the scope of Plato Arabus, Kraus notified the former that he wished from now on to restrict his editorial duties to the texts to which he was personally assigned. ${ }^{66}$ Vague about his rationale, Kraus, nonetheless, connects his partial withdrawal to the circulation of the "semi-official" (halboffizielles) conspectus, which he tepidly endorsed: he found it agreeable on the whole but inflexible (Mit dem Plan bin ich in grossen und ganzen... einverstanden; man sollte sich nicht schon jetzt an streng einzuhaltende Linie binden). Increasing public attention seems to have spurred Kraus to assess whether Plato Arabus was promoting a profile of him that was reflective of his interests as an "orientalist." 67 As the following section will establish, Kraus was a fastidious collaborator who took responsibility for the quality of both his own and his partner's work, so his inability to align the project with his own disciplinary agenda may underlie his rejection of Walzer's initial offer of greater editorial authority.

\section{HIN-UND-HERSCHREIBEN, 1937-51}

The new year saw Kraus and Walzer return to Com. Tim. after a series of life changes - the former remarried and began lecturing in Cairo whereas the latter's position in Rome had become precarious. ${ }^{68}$ Because Kraus had already settled the Arabic text in preparation for its submission to Orientalia, his exchange with Walzer over 1937 mainly concerns the composition of the Latin translation and notes, which featured parallels with the Timaeus, reconstructions of the Greek, and philological interpretations. ${ }^{69}$ Besides the philological commentary, Kraus

65 In addition to this autumn note (a postcard with an illegible postmark), Klibansky inquires on 26 October 1936 into whether Kraus' participation is contingent on the receipt of financial compensation, as Walzer's was. See ARC. $4^{*} 1656 / 458$.

${ }^{66}$ See Kraus' 3 August 1936 letter in ARC. $4 * 1656 / 111$.

${ }^{67}$ Kraus, on the other hand, brings up the omission of his name in the title page of the draft conspectus; as he reminds Walzer, half of the concept and drafting of the program is his work.

68 In a letter dated to 28 January 1937, Kraus announces to Walzer that he married (Bettina Strauss) a few weeks earlier. See ARC. $4^{*}$ 1656/111. 
had charged Walzer with producing the Latin translation, which exceeded his expectations (die lateinische Uebersetzung liesst sich wider alles Erwarten meinerseits... ausgezeichnet), on the basis of his earlier French rendition for Orientalia; he was to handle the glossaries (i.e., the Greek-Arabic, Arabic-Greek indices), the analysis of the translation's "value" (Wert) for reconstructing the lost Greek, and engaging a printer. ${ }^{70}$ Proofreading the Latin in three blocks, Kraus blamed their back-and-forth communication for what might seem like excessive and pedantic markups on his part; these comments were to instruct Walzer on how to "let the original Greek text shimmer through the Arabic and Syriac" (Sie muss vielmehr, ueber das arabische und syrische hinweg, den griechischen Urtext durchschimmern lassen). ${ }^{71}$

The four recensions of the Latin translation in the Kraus Papers two ribbon copies, a holograph version, and author's proofs - expose the interventions that Kraus made to rephrase Walzer's "slavish" (sklavisch) draft. A comparison of the wording of Com. Tim. § 14, Galen's summary of the dialogue's etiology of pleasure (64a2-c6), across the four versions shall suffice to illustrate how he transformed the Latin from a literal to concise rendering that more freely adapts the Arabic's syntax. In describing how pleasure depends on the degree of ease by which the body returns to its natural state (64d1-3), the Arabic of $\S 14$ utilizes a nominal predicate phrase with a conjunction - matā kānat harakatuhu sahlatan $a w$ cusratan ("whenever its movement is easy or difficult") - to convey the link between the sensation and movement towards health. ${ }^{72}$ Walzer's Latin translation, in a single-spaced ribbon copy [Figure 1], reproduces the Arabic grammar through an adverbial conjunction, a noun modified by a possessive pronoun, a verb of being, and two predicate adjectives separated by a disjunctive conjunction: prout eius motus facilis aut diff-

${ }^{69}$ Kraus' letter on 5 December 1937 (ARC. $4^{*}$ 1656/111) instructs Walzer to arrange the notes into three apparatuses ("A," "B," and "C"). Although Kraus may have felt confident about the Arabic text, he, nonetheless, proposed on 9 November 1937 that they ask David Baneth (1893-1973) to proofread it (ARC. $4^{*} 1656 / 111$ ).

${ }^{70}$ See Kraus' 14 March 1937 message (ARC. $4^{*} 1656 / 111$ ). After receiving a price quote from a Belgian printer, Klibansky counselled that they should find a printer in the "Orient" and set the Arabic and Latin texts successively, rather than alongside each other, to reduce costs (see his missive on 26 October 1936, ARC. $4^{*} 1656 / 458$ ). Kraus first approached the Cairene printers at the Institut français d'archéologie orientale and Lağnat at-ta lïf wa-t-tarğama wa-n-našr before hiring Imprimerie catholique in Beirut.

${ }^{71}$ For Kraus' apology, see his letter on 9 November 1937, and for the above quotation, his missive later that month on the 22nd (ARC. $4^{*} 1656 / 458$ ).

72 Galen, Compendium Timaei, p. 18, 1. 16. 
cilis est. ${ }^{73}$ The close correspondence between this draft of the Latin and the Arabic may signify that Walzer preferred to work off the Arabic instead of Kraus' French translation, which could, on the other hand, have been very literal. Unsatisfied with Walzer's interpretation, Kraus strikes out eius motus and est in his handwritten copy [Figure 2], changes the adjectives to adverbs (derived from the neuter, singular, nominative / accusative form of the adjective), and verbalizes motus: prout facile aut difficile movetur. ${ }^{74}$ The second ribbon copy [Figure 3] makes two modifications to this translation: perhaps concerned that the subject of movetur is ambiguous, Kraus added haec substantia (in parenthesis), which picks up al-ğawhar in the preceding clause of the Arabic and replaces Walzer's nonspecific eius; he substituted the classical difficulter for difficile as well. ${ }^{75}$

Unlike his emendations of the Latin, most of Kraus' revisions to Walzer's notes were not incorporated into the published text. His lengthier comments seem on the whole to be loose reflections on the abridgement's content in light of his ongoing research - on the alchemist Ğābir ibn Hayyān, in particular. ${ }^{76}$ Having previously edited select treatises by "Ğābir," Kraus was formulating around this time broader theses about the corpus' authorship and philosophical background that would appear in his Jābir ibn Hayyān: Contribution à l'histoire des idées scientifiques dans l'islam (1942-3). ${ }^{77}$ Kraus' work on Ğābir appears to have been generative for his thinking on Com. Tim., as his excurses on these compositions' theorization of matter reveals. His preoccupation with Ğābir's understanding of matter first manifests in a 17 February 1936 message to Walzer that digresses on the alchemist's terminology

73 This typewritten draft seems to be the oldest version of the translation, and therefore from Walzer, because it includes unparalleled readings and marginalia that appear in the bodies of the other copies. Paul Kraus, Papers [Box 22, Folder 15], Special Collections Research Center, University of Chicago Library (unnumbered folio).

${ }^{74}$ Paul Kraus, Papers [Box 22, Folder 15], Special Collections Research Center, University of Chicago Library (unnumbered folio).

${ }^{75}$ Paul Kraus, Papers [Box 22, Folder 15], Special Collections Research Center, University of Chicago Library, fol. 71. According to $L S$ s.v. "difficilis IIa," the use of difficile as an adverb does not appear in pre-Augustan literature. Cf. difficulter; see $O L D$ s. v. "difficiliter." This copy was probably typed by Bettina Strauss, who prepared all of Kraus' manuscripts during their marriage (See Kraemer, "The death of an orientalist," p. 198-9).

${ }^{76}$ As mentioned above (p. 232), Kraus had also published two substantial articles on Abū Bakr al-Rāzì.

${ }^{77}$ Paul Kraus, Muhtāar rasāo ${ }^{\circ} i l$ Ğābir ibn Hayyān: essai sur l'histoire des idées scientifiques dans l'islam, volume I: textes choisis (Paris, 1935). 
for the concept. ${ }^{78}$ He records the Arabic equivalents for the Greek hyle in Ğābir: the "old philosophical translation" (eine alte philos[ophische] Übersetzung) țina, the "oral form" (mündl[ich] Tradizion) hayūla, and the "Persian derivative" $m \bar{a} d d a .{ }^{79}$

In his "remarks" (Bemerkungen) on pages 11-16 of Walzer's Latin draft, Kraus relates the Galenic summary to Ğābir when glossing the former's definition of perceptible things (res magnae quae sensu videntur) as compounds of "other things that do not belong to the same genus" (ex aliis rebus permixtis quae non eiusdem generis sunt). ${ }^{80}$ According to Kraus, Galen rejects with these words the "worldview" of Plato's Timaeus, which reduces sensible bodies to geometric corpuscles of invisible atoms, following Aristotle's criticism that what is visible and heavy cannot result from something immaterial. Instead, Galen materializes (Materielisierung) the dialogue's corpuscles by inserting "something else" (aliis rebus) into their structure that can account for these bodies' perceptibility. ${ }^{81}$ Kraus concludes that this same transformation of the atomic corpuscles of the visible cosmos from geometric to material bodies can be seen in Ğābir. ${ }^{82}$

Kraus' letter from February 1936 documents that he had been in-

${ }^{78}$ See ARC. $4^{*} 1656 / 55$.

${ }^{79}$ He traces the etymology of $m \bar{a} d d a$ ultimately to the Greek mētēr ("mother"). Furthermore, Kraus lists the Hebrew equivalent homer. None of these foreign words are romanized in the handwritten letter but are given in their original scripts.

80 These draft pages (ARC. $4 * 1656 / 111$ ) equate to $\S 10$ of the print version (Galen, Compendium Timaei, 59-61), which treats Tim. 54d-57d. The quotation is at Galen, Compendium Timaei, p. 60, 1. 12 (cf. the Arabic at p. 15, 1. 9-10).

${ }^{81}$ Kraus observes another materializing tendency in Galen's association of Plato's receptacle of becoming with matter; see Com. Tim. § 8, Compendium Timaei, p. 13, 1. $4($ Arabic $)=$ p. 57, 1. 14 (Latin) .

${ }^{82}$ Diese Worte denen nicht nur nicht bei Plato entspricht, sondern die vollkomme aus dem Weltbild des Timaeus herausfallen (fuer Plato sind die sichtbaren Koerper die Summen der unsichtbaren Atome ohne dass irgendetwas anderes hinzutreten wuerde) scheinen mir fuer die galensche Interpretation der platonischen Physik sehr bedeutsam. Aristoteles hatte ausfuehrlich (vgl. die Stellen bei E. Sachs) die platonische (und pythagoraeische) Lehre von den geometrischen Koerpern kritisiert. Hauptargument war dabei, dass aus etwas nicht-materiellem (nicht-schweren) wie es die geometrischen Koerper sind durch Addition niemals etwas materielles, sichbares und schweres (apton horaton te wie Plato sagt), entstehen koenne. Um diesem Einwand zu begegnen und um zugleich den Timaeus mit Aristoteles auszugleichnen, sagt Galen, dass bei der "Materielisierung" der geometrischen Atome noch "etwas anderes" hinzutritt. Was das sei, behaelt er aber wohlweislich fuer sich. Uebrigens sind, da Galen die platonische Xōra ausgemerzt hat, die Atomkoerper nicht mehr rein geometrisch, sondern selbst schon materiell. Die ganze Frage ist in der Einleitung naehe zu behandeln. NB gibt es aehnliche Probleme bei Gābir. 
vestigating the Pythagorean and Neoplatonic roots of Ğābir's science; thus, his earlier analysis of the alchemist's adaptation of what his 1937 "remarks" characterize as both a Platonic and Pythagorean doctrine may have helped him to pick out Galen's interpretive stamps on the Timaeus. ${ }^{83}$ Although Kraus elsewhere calls Walzer's attention to Ğabir's access to Com. Tim. in citing a reference to the summary in "The book of the search" (Kitāb al-baht $\underline{t}$ ), his "remarks" do not allege that Galen influenced the Arabic writer on the subject of matter. ${ }^{84}$ At any rate, Kraus' longstanding interest in Ğābir (going back to his studies with Julius Ruska in Berlin) may have drawn him to the editorial projects of Com. Tim. and Plato Arabus, for the former is an occasional point of reference in the Ğabirian Corpus and the latter provided a platform from which he could delve deeper into the Platonic aspects of Islamicate alchemy. ${ }^{85}$

By 1939, Kraus had delivered the edition of Com. Tim. to the printer in Beirut, which had almost finished the first typescript of the manuscript before WWII broke out. ${ }^{86}$ Paper and typeface shortages in addition to the technical challenges of printing a bi-directional text contributed to a ten-year postponement of publication, during which the two editors and, after Kraus' death, Walzer by himself reviewed several rounds of proofs. ${ }^{87}$ Dating to $1941,1945,1947$, and 1949, the proofs demonstrate that compromises to the edition's content were made at this final phase. For instance, as well as containing misprints, the 1951 publication lacks an index nominum, which they were compiling at the

${ }^{83}$ Kraus writes in his February letter, "In Jabir I have just gotten a good bit further. I can just about articulate all of his science (i. e., natural science) as Pythagoreanism mixed with Neoplatonic elements. I have found almost all the elements (packed away) in Pythagorean literature again and believe that in this form the work will be a very nice contribution to ancient science" (Im Jabir bin ich just ein gutes Stuck weitergekommen. Ich kann just seine ganze Wissenschaft (d.h. Naturwissenschaft) als mit neuplatonischen Elementen versetzten Pythagoräismus außprechen. Ich habe fast sämtliche Elemente (verstaut) in der Pythag. Literatur wiedergefunden und glaube daß in diese Form die Arbeit ein ganz schönes Beitrag zu antiken Wissenschaft sein wird).

${ }^{84}$ Kraus includes the citation, which does appear in the published edition (Galen, Compendium Timaei, p. 37 n. 31-2 [Latin]) in his remarks on the first third of Walzer's Latin translation (on 28 January 1937, ARC. $4 * 1656 / 111$ ).

${ }^{85}$ Kraus addresses the role of the Timaeus in Ğābir in Jābir ibn Hayyān: Contribution à l'histoire des idées scientifiques dans l'islam (Paris, reprinted 1986), p. 48-51, 17485.

${ }^{86}$ See "Presidential address," Proceedings of the British Academy (1939), 26.

${ }^{87}$ For Kraus' dissatisfaction with the quality of the initial typescript, see his 1 July 1939 letter to Walzer (ARC. $4 * 1656 / 55$ ). 
proof stage, so their underlining of all proper names suggests. ${ }^{88}$ Furthermore, when the two were preparing the Latin translation, Ritter had discovered another witness to the text in the library of the University of Istanbul. ${ }^{89}$ The disruption of postal services during wartime might explain why Kraus (presumably) did not begin to collate the new manuscript, which Ritter may have photographed or transcribed for him, until 1941, after the draft edition had been dispatched to Beirut - although he had known about the find since $1937 .{ }^{90}$ In consideration of the cost of printing a substantially revised Arabic apparatus, on top of the mounting delay, the Warburg, which was apprised of the new witness' existence only in 1948, may have directed Walzer to select the unique readings from Kraus' exhaustive collations to include in a section of "corrigenda et addenda." "1

The published version of Com. Tim. does not list all the errors and recommendations marked in the proofs. Whereas the "corrigenda et addenda" catalog all Greek accenting errors, they omit revisions to punctuation, changes to internal and external references, Latin misspellings (e. g., mulctabitur for mulcabitur), and conjectures about the Arabic and lost Greek. ${ }^{92}$ Marginalia in the Arabic-Greek indices, for which Kraus

${ }^{88}$ E. g., the 1941 proofs (ARC. $4 * 1656 / 180$ ) flag that $\S 24$ reads $y a^{c} u m m u h u$ instead of $y a^{c}$ lamuhu. The mistake appears in the published text; see Galen, Compendium Timaei, p. 33, l. 14 (Arabic). Walzer may have scrapped the plan for an index nominum when he was faced with compiling the indices anew after Kraus' death (see "Presidential address," Proceedings of the British Academy [1945], 12).

89 The published edition abbreviates the manuscript as "A 1458" (Galen, Compendium Timaei, p. xii); the proofs refer to it as "MS U" (see ARC. $4^{*} 1656 / 180$ ).

${ }^{90}$ Kraus announces this manuscript discovery to Walzer on 5 December 1937 (ARC. $\left.4^{*} 1656 / 55\right)$.

${ }^{91}$ On 15 October 1948, Gertrud Bing (1892-1964), who would assume the directorship of the Warburg in 1954, admonished Walzer for not informing Klibansky earlier about the new manuscript find (see ARC* 1656/180). See Galen, Compendium Timaei, p. xii, which hypothesizes a common origin for the $\mathrm{Es}^{\mathrm{c}} \mathrm{ad}$ and Istanbul University MSS.

92 The internal references are to the edition's praefatio. Apart from neglecting updated primary source references (e. g., Pohlenz's 1929 instead of Bernardakis' 1891 text of Plutarch's De fato), the corrections also leave out citations to new secondary sources, such as a piece by Ludwig Edelstein on Tim. 84d-e in the American journal of philology - the proofs incorrectly date the paper to 1941 when the citation should be to a book review by Edelstein in AJP, 61 (1940), 221-229. The Latin misspelling is at Galen, Compendium Timaei, p. 25, n. 7. Beside the footnote "nequaquam... adhibenda" on p. 93, n. 22 (of the author's proofs), Walzer speculated (in English) that

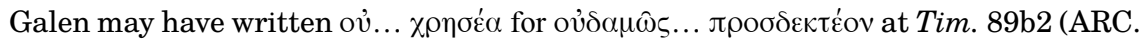
$4^{*} 1656 / 180$ ). At the margin of p. $85 \mathrm{n}$. 18-20, which highlights the summary's departure from the dialogue's account of the corruption of blood (Tim. 82e3-7), Walzer 
was originally responsible, record Walzer's disagreement with his collaborator's hypotheses about the Greek underlying certain Arabic terms and phrases. For example, he dismisses as "nonsense," "unconvincing," and "doubtful?" (original punctuation) the use of ğacala to translate ov-

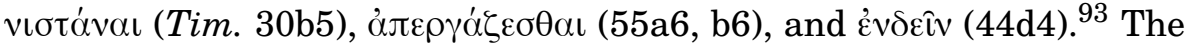
final "index Greco-Arabicus" does not offer alternatives to these equations, however. ${ }^{94}$ Therefore, Walzer can take credit for both initiating and bringing to completion an edition whose every feature - introduction, text, translation, notes, and end matter - bears witness, nonetheless, to the labor of another hand.

\section{CODA: MODERN RECEPTIONS}

Only a handful of studies of Com. Tim. have appeared since the publication of the editio princeps more than a half century ago. ${ }^{95}$ The text's accessibility in Arabic and Latin, which now creates rather than resolves Sprachschwierigkeit for many scholars, has almost certainly impeded wider inquiry into it. The summary seems to suffer as well from the perception that it is philosophically uninteresting because it just recapitulates the Timaeus. ${ }^{96}$ The emphasis placed on the exegeses' literal representation of the dialogue furthers this derivative impression, which arguably stems from Kraus and Walzer's prioritization of the reconstruction of the lost Greek Urtext. ${ }^{97}$ While the editors' disproportionate at-

has scrawled "misunderstanding" (again in English) to indicate, perhaps, that the Arabic translator mistook Timaeus' attribution of diverse qualities to normal blood to be a description of pathological kinds of blood.

93 See ARC. $4 *$ 1656/180.

${ }^{94}$ Cf. Galen, Compendium Timaei, p. 46 (Arabic).

${ }^{95}$ See André-Jean Festugière, "Le Compendium Timaei de Platon," Revue des études grecques, 65 (1952), 97-118; Rashed, "Le prologue perdu;" Rüdiger, "Plato's Timaeus in the Arabic tradition;" Aileen Renée Das and Pauline Koetschet, "Galen's Synopsis of Plato's Timaeus," in Philip van der Eijk (ed.), Galen on human nature. Volume 2 (forthcoming).

${ }^{96}$ See John Dillon, The middle Platonists: 80 B. C. to A. D. 220, revised ed. (Ithaca, 1996), p. 339, who overlooks Com. Tim. in addition to giving short shrift to Galen's longer exegesis of the Timaeus, "On the medical statements in Plato's Timaeus."

${ }^{97}$ For this focus on the summary's close adherence to Plato's text, see Heinrich Dörrie and Matthias Baltes, Die philosophische Lehre des Platonismus, vol. VI.1, Von der "Seele" als der Ursache aller sinnvollen Abläufe, Bausteine 151-168: Text, Übersetzung, Kommentar (Stuttgart, Bad Cannstatt, 1993), p. 312; Riccardo Chiaradonna, "Galen and middle Platonism," in Chris Gill, Tim Whitmarsh, and John Wilkins (ed.), Galen and the world of knowledge (Cambridge, 2009), 243-60, at p. 245; and Arnzen, "Plato's Timaeus in the Arabic tradition." On how ancient abridgements 
tention to correspondences with the Timaeus in, for instance, the notes and indices may work to justify their conjectures about the Greek, it also has the effect of minimizing Galen's interventions. The Greek that they see "shimmering through" appears to be Plato's rather than Galen's. ${ }^{98}$

The close relationship that the editio princeps of Com. Tim. constructs between Galen and Plato's texts sits uncomfortably with Kraus' "remarks" - infrequent though they are - about the synopsis' departure from the dialogue's "worldview." ${ }^{99}$ It dovetails, on the other hand, with Klibansky's notion of the position of Plato Arabus in the Platonic tradition, as this paper has maintained. His proposal for the Corpus Platonicum attributed to the works constitutive of Plato Arabus the role of preserving the continuity of the Platonic tradition by not only bridging the classical and medieval pasts but also by bringing premodern readers into contact with a "less speculative," presumably more authentic, Plato. ${ }^{100}$ Recent analyses of Com. Tim. have begun to contest the claim that Arabic Platonism, for which Plato Arabus is a metonym, is "closer to the [Platonic] text" through their sensitivity to how the different contexts and agendas of both Galen and the Arabic translator(s) give texture to the summary. ${ }^{101}$ The textual history outlined herein has set out to reveal the edition's implication in an analogous complex of motives that had real-world stakes for the scholars involved in its making, who had been marginalized from the "main stream" of academic and social life in the lead-up to WWII.

\section{APPENDIX: TIMELINE OF THE PUBLICATION OF COM. TIM. AND RELEVANT EVENTS}

1919-1927 Walzer pursues a higher education in Berlin.

1926 Ritter relocates to Istanbul after his arrest for homosexuality and

mask their own selectivity, see Rosalind Frances MacLachlan, "Epitomes in ancient literary culture," Ph. D. dissertation, Cambridge University (2004).

${ }^{98}$ Perhaps in implicit recognition of the speculative nature of the Greek-Arabic indices of Kraus and Walzer's edition, the Glossarium Graeco-Arabicum (http://telota. bbaw.de/glossga/) does not utilize this source, despite drawing the bulk of its materials from the glossaries of editions of Arabic translations of Greek scientific and philosophical texts.

${ }^{99}$ See p. 246 above.

${ }^{100}$ See p. 229 above.

${ }^{101}$ E. g., see Rashed, "Le prologue perdu," and Das, Galen and the Arabic reception, who read Com. Tim. in light of Galen's professional ambitions. For the translator's role in shaping later understandings of the dialogue's doctrines, see Adamson, "Platonic pleasures in Epicurus and al-Râzî,” p. 83-5. 
subsequent dismissal from the University of Hamburg.

1927-1933 Kraus is in Berlin.

1929 Klibansky submits his doctoral thesis, in which he refers to a research program on the direct tradition of Plato during the Middle Ages, encompassing Latin, Arabic, and Byzantine lines, at the University of Heidelberg.

1932 Walzer submits his habilitation. Kraus and Walzer possibly meet and devise a plan to collaborate on an edition of Com. Tim.

1933 Klibansky submits his initial plan for a Corpus Platonicum to Fritz Saxl.

April Kraus leaves for Paris.

From August to September Walzer visits Istanbul.

October Walzer is fired from his post in Berlin.

1934 Ritter and Walzer publish their list of Istanbul medical MSS, which announces the latter's plans to prepare an edition of Com. Tim.

1934/5 Saxl mentions in an annual report of the Warburg Institute Klibansky's plan for a Corpus Platonicum.

193527 January Kraus approaches Pohl about publishing an edition of Com. Tim.

7 July Klibansky offers Walzer the task of editing Plato Arabus.

11 November Klibansky asks Walzer to reserve Com. Tim. for Plato Arabus and withdraw it from Orientalia.

193612 June Saxl informs Walzer that the AAC has awarded him $£ 250$ to dedicate his time exclusively to Plato Arabus.

24 June Kraus instructs Walzer to take charge of the Latin translation of Com. Tim.

21 July Klibansky omits Plato Syrus and Hebraeus from Plato Arabus.

23 July Kraus reports to Walzer that he has withdrawn their edition from Orientalia.

3 August Kraus requests a more limited editorial role in Plato Arabus.

10 October Klibansky asks Walzer for clarification about whether Kraus will serve as co-editor of Plato Arabus.

1937 The "Presidential address" in the $P B A$ formally introduces the plan for a Corpus Platonicum with Klibansky as its "future editor." Throughout the year, Kraus sends his revisions and comments on Walzer's Latin translation and notes.

5 December Kraus communicates to Walzer Ritter's discovery of 
another Istanbul MS of Com. Tim.

1939 The $P B A$ (1939: 26) reports that the first Latin and Arabic fascicle of the Corpus Platonicum are "nearly complete in type and will be published shortly." Klibansky publishes The continuity of the Platonic tradition.

1940-1 The annual report of the $P B A$ (1940-1: 10) records that, apart from the index and a final revision, the edition of Com. Tim. is in an advanced state of printing.

November 1941 Kraus and Walzer receive proofs from Imprimerie catholique in Beirut.

1942 Walzer becomes a fellow at Oriel College, Klibansky's academic home.

1943 The PBA (1943: 6) reveals that "two remaining sheets," "containing the title-pages, the end of the Latin translation, and the Indices," still need to be printed.

1944 October 12 Kraus commits suicide in his apartment in Zamalek, Cairo.

1945 The $P B A$ (1945: 12) announces the death of Kraus and states that the indices (Greek-Arabic, Arabic-Greek) are outstanding and are being compiled anew (by Walzer).

November 1945 Walzer receives author's proofs from Beirut.

1946 The Arabic-Greek and Greek-Arabic indices are sent to Imprimerie Catholique.

1947-8 The PBA (1947-8: 9-10) states that "the whole Greek-Arabic index and the greater part of the Arabic-Greek Index are now in print." The British Academy expects that the text, "edited by Dr. P. Kraus and Dr. R. Walzer" will appear at the beginning of 1949 . 15 October 1948 Gertrud Bing censures Walzer for not notifying Klibansky earlier about Ritter's discovery of another Istanbul MS.

1948-9 The $P B A$ (1948-9: 11) relates that a small part of the ArabicGreek index has yet "to be set up in print" and revises the publication date to the following year.

April 1949 Walzer receives author's proofs from Beirut.

1949-50 Imprimerie Catholique finishes printing Com. Tim. and dispatches the sheets to England.

1951 The editio princeps of Com. Tim. appears in print.

Acknowledgement. I wish to thank the Special Collections Research Center at the University of Chicago, The National Library of Israel, and the Bodleian Library for granting me access to the Paul Kraus, Richard Walzer, and Soci- 
ety for the Protection of Science and Learning Archives. I am also appreciative of Anna Cornell for their assistance with transcribing and translating the more orthographically challenging documents from the Paul Kraus Archive. In writing this paper, I have benefited from conversations with my colleague Will Stroebel about early twentieth-century printing and textual production in the Mediterranean and from the comments of the journal's anonymous reader. Finally, my gratitude goes to Mark Nightingale for translating this article's abstract into French. 
FIG. 1
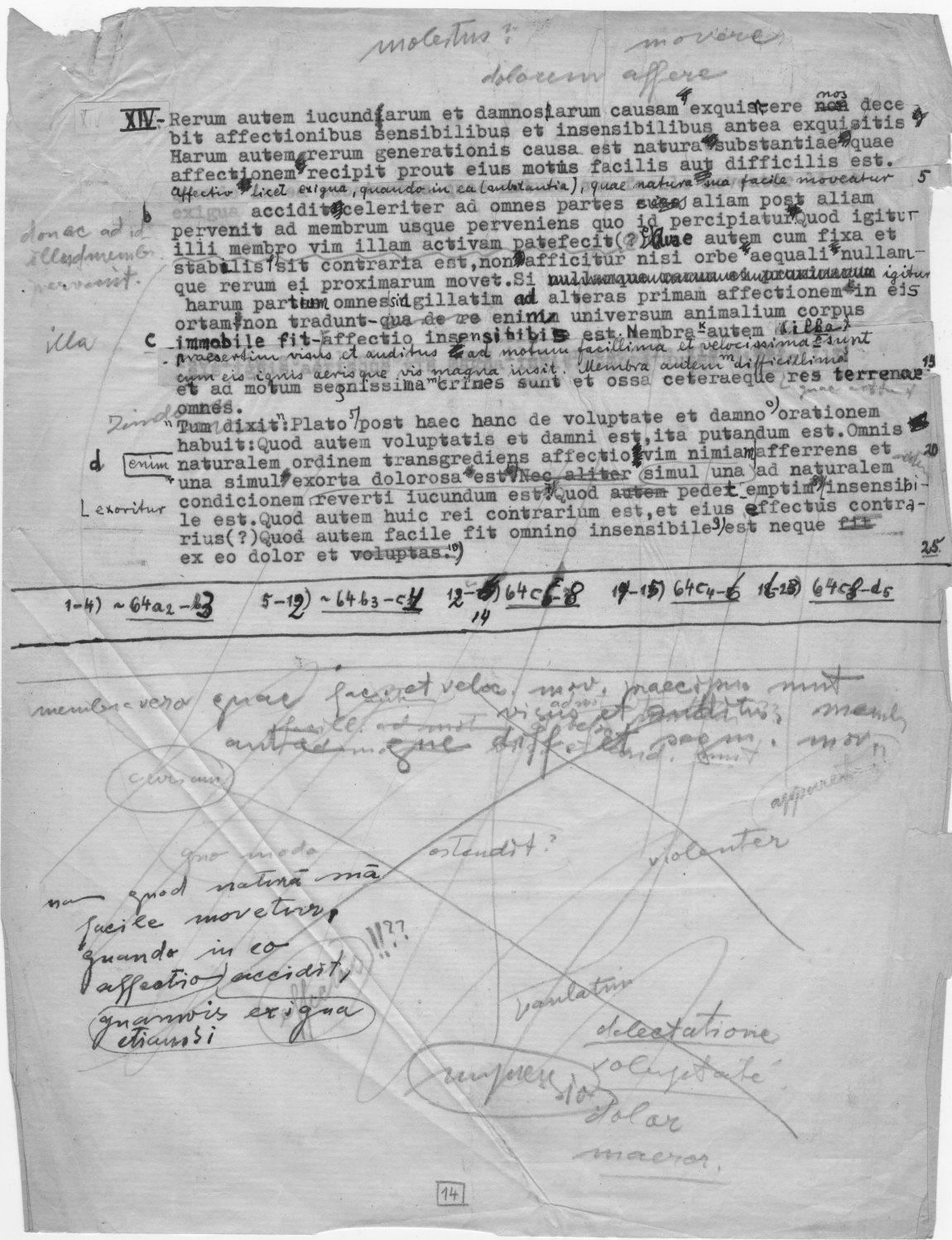

(C) Hanna Holborn Gray Special Collections Research Center, University of Chicago Library. 
Fig. 2

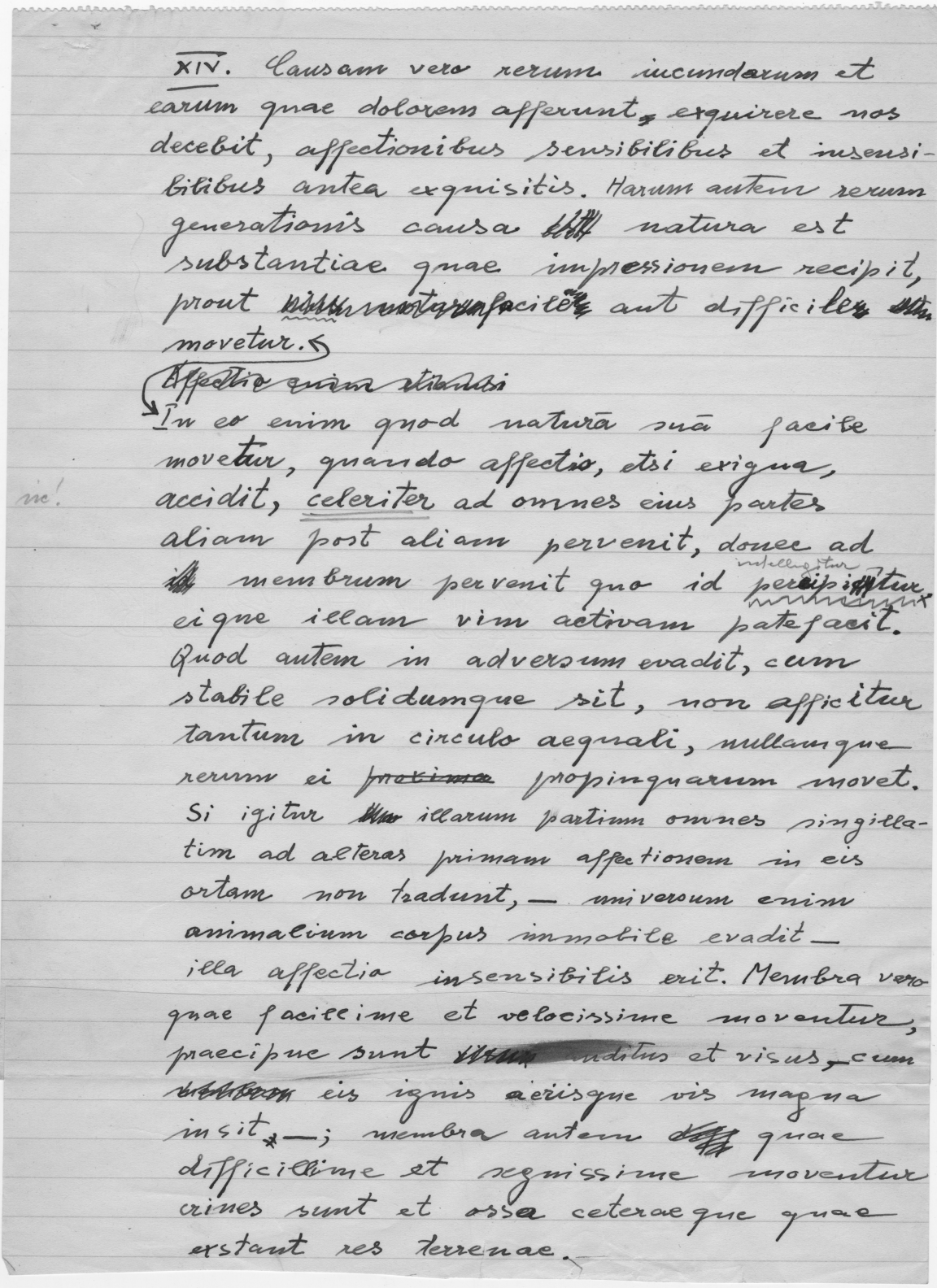

(C) Hanna Holborn Gray Special Collections Research Center, University of Chicago Library. 


\section{FIG. 3}

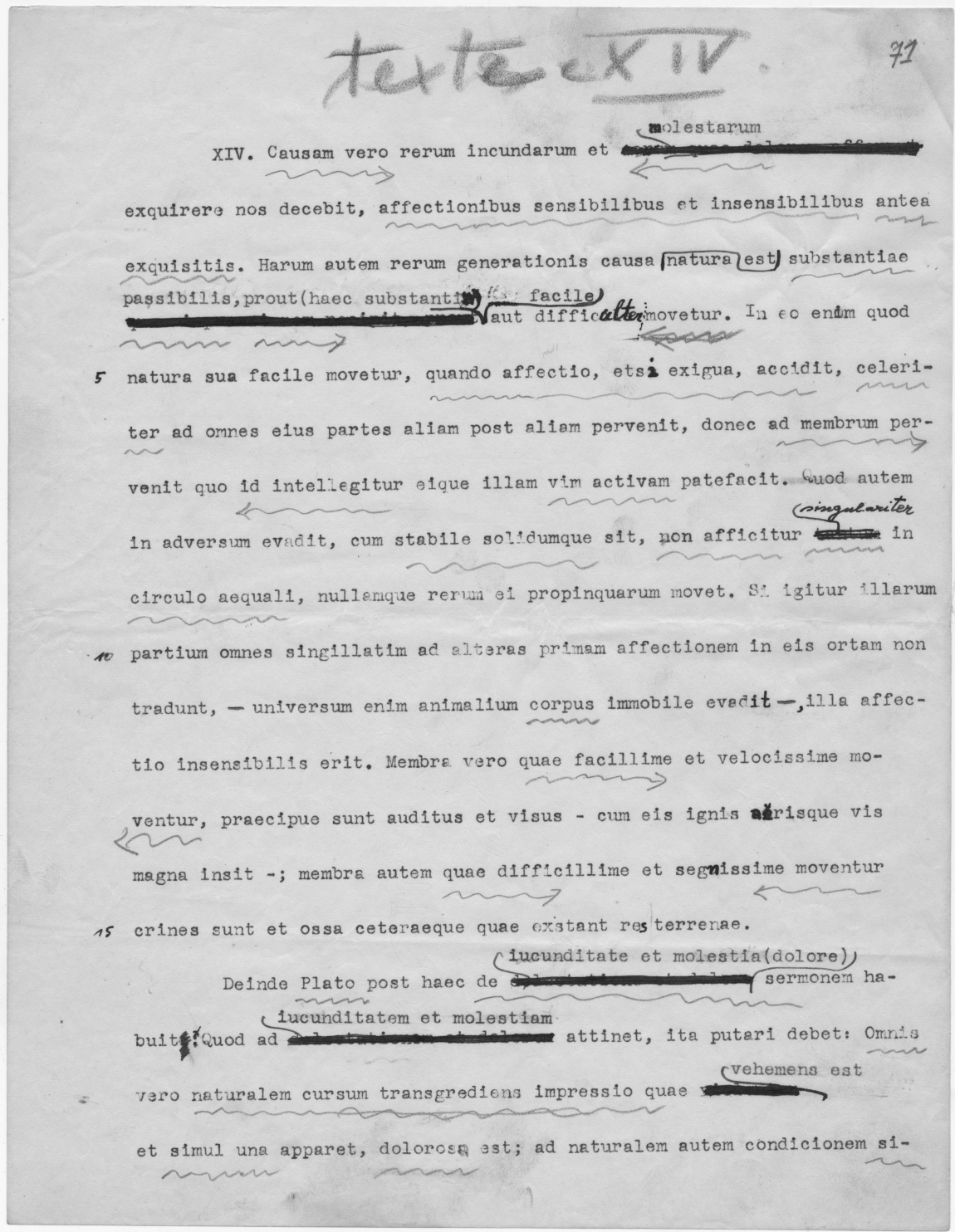

(c) Hanna Holborn Gray Special Collections Research Center, University of Chicago Library. 